the patients with no neurological deficit. One patient who showed a personality change was found to have a small left thalamic infarct. Another who became severely depressed was considered to have lived with severe domestic stress for many years. A third patient became debilitated with various illnesses and died two years later following a myocardial infarction. At necropsy widespread atheroma was found. Other patients deviated from the general pattern of emotional well being in proportion to the degree of stress they were experiencing in other aspects of their lives. Such factors included divorce, bankruptcy, and death in the family.

\section{Conclusion}

Our experience of the survivors of subarachnoid haemorrhage suggests that a positive approach to prognosis is warranted if a neurological deficit has not occurred. One year after the haemorrhage no cognitive deficits were evident in our patients and residual symptoms seemed to be minor. The typical pattern in a straightforward case was a gentle convalescence and then the patient returning to a normal lifestyle by three months. In treating and managing survivors of subarachnoid haemorrhage normality should be encouraged.

We thank Professor E K Warrington for her advice and $\mathrm{Mr}$ J Bartlett, Mr M Sharr, Mr Wainwright, and Dr Robson for giving us access to their patients. The work was supported by a grant from Locally Organised Research Scheme South East Thames Regional Health Authority.

1 Adams H, Kassell NF, Torner JC, Nibbelink DW, Sahs AL. Early management of aneurysmal subarachnoid hemorrhage. F Neurosurg 1981;54:141-5. Kravenbuhl JA, Yasaril MG, Flamm ES, Tew JM. Microsurgical treatment of intracranial saccular aneurysms. F Neurosurg 1972;37:678-86.

intracranial saccular aneurysms. F Neurosurg $1972 ; 37: 678-86$.
Testa C, Andreoli A, Arista A, Limoni P, Tognetti F. Overall results in 304 Testa C, Andreoli A, Arista A, Limoni P, Tognetti F. Overall results in 304
consecutive patients with acute spontaneous subarachnoid hemorrhage. Surg Neurol 1985;24:377-85.

4 Fortuny LA, Prieto-Valiente L. Long-term prognosis in surgically treated intracranial aneurysm. Part 2: Morbidity. I Neurosurg 1981;54:35-43.

5 Ropper AH, Zervas JT. Outcome 1 year after SAH from cerebral aneurysm management morbidity, mortality and functional status in 112 consecutive good-risk patients. I Neurosurg 1984;60:909-15.

6 McKenna P, Willison JR, Lowe D, Neil-Dwver G. Cognitive outcome and quality of life one year following subarachnoid hemorrhage. Neurosurgery 1989;24:361-7.

(Accepted 24 May 1989)

\title{
Energy expenditure in children with type I diabetes: evidence for increased thermogenesis
}

\author{
Manfred J'Müller, Alexandetyon zur Mühlen, Hans UlLautz, Friedrich W $\underline{\text { Schmidt, }}$ \\ Margarete Daiber, Peter Hürter
}

Medizinische Hochschule

Hannover, Hanover, Federal Republic of Germany

Manfred J Müller, MD, department of internal medicine

Alexander von zur Mühlen, $\mathrm{MD}$, head, division of endocrinology

Hans U Lautz, MD, department of internal medicine

Friedrich W Schmidt, MD, head, division of gastroenterology and hepatology

Kinderkrankenhaus auf der Bult, Hanover

Margarete Daiber, MD Peter Hürter, MD, head, department of paediatrics

Correspondence to: Dr M J Müller, Medizinische Hochschule Hannover, Zentrum Innere Medizin und Dermatologie, Abteilung Gastroenterologie und Hepatologie, D-3000 Hanover 61, Federal Republic of Germany.

Br Med f 1989;299:487-91

\section{Abstract}

The aim of the study was to assess whether increased energy expenditure causes the negative energy balance (tissue catabolism) commonly seen in children with insulin dependent (type I) diabetes. Resting metabolic rate and thermogenesis induced by adrenaline were measured in five healthy children and 14 children with type I diabetes who were all free of clinical signs of late complications of diabetes mellitus but differed in their degree of glycaemic control (in eight glycated haemoglobin concentration was $<10 \%$ and in the six others $\geqslant 10 \%)$. When compared with the control subjects children with type I diabetes had normal resting metabolic rates but their urinary nitrogen excretion was significantly raised $(11.5$ (SD 5.4$) \mathrm{mg} / \mathrm{min}$ in those with glycated haemoglobin concentration $<10 \%$, $11.6(5 \cdot 2) \mathrm{mg} / \mathrm{min}$ in those with concentration $\geqslant 10 \%$ $v 5.4(3.0) \mathrm{mg} / \mathrm{min}$ in control subjects). During the infusion of adrenaline the diabetic children showed a threefold and sustained increase in thermogenesis and disproportionate increases in the work done by the heart, in lipid oxidation rate, and in plasma concentrations of glucose, free fatty acids, and ketone bodies. The increased thermogenic effect of adrenaline did not correlate with the degree of glycaemic control.

Increased thermogenesis may explain the tissue wasting commonly seen in children with type I diabetes during intercurrent stress.

\section{Introduction}

Alterations in energy expenditure contribute to energy balance and thus to changes in body weight. ${ }^{12}$ Patients with type II diabetes that is resistant to insulin are commonly overweight and show a blunted thermogenic response to a meal and reduced stimulation of energy expenditure by the sympathetic nervous system. ${ }^{2}$ Whether defective thermogenesis is primary or secondary in type II diabetes is not known, but limited energy expenditure predisposes to a positive energy balance, weight gain, and thus obesity.

When compared with patients with type II diabetes mellitus many patients with insulin dependent (type I) diabetes are also resistant to insulin and have a normal or commonly reduced body weight. ${ }^{3.5}$ Little is known, however, about their daily energy expenditure. Resting metabolic rate was reported to be increased in type I diabetic patients during severe hyperglycaemia and ketoacidosis and to return to normal values within three hours after insulin replacement. ${ }^{6}$ This finding would partly explain tissue wasting in patients with poorly controlled type I diabetes and also their weight gain after adequate insulin replacement. ${ }^{\top}$ In addition, in patients with poorly controlled type I diabetes the thermogenic effect of a meal was abnormal and the response to infused noradrenaline reduced. ${ }^{8}$ This defect was not improved by continuous infusion of insulin subcutaneously despite optimal glycaemic control. ${ }^{8}$ The thermogenic effect of noradrenaline was, however, normal in three patients given biguanides with insulin, ${ }^{8}$ which suggests that insulin resistance causes defective thermogenesis in both type I and type II diabetes. By contrast, the responses of several energy consuming processes-for example, the work of the heart and hepatic gluconeogenesisto $\beta$ adrenoceptor agonists were reported to be enhanced in adult patients with type I diabetes independently of their glycaemic control..$^{910}$

The fact that increased $\beta$ adrenergic sensitivity predisposes to a negative energy balance partly explains the differences in body weight between type I and type II diabetic patients. To investigate this hypothesis we selected a group of 14 children of normal weight with type I diabetes who differed in the degree of their glycaemic control (as reflected in their glycated haemoglobin concentrations) but had no experience of 

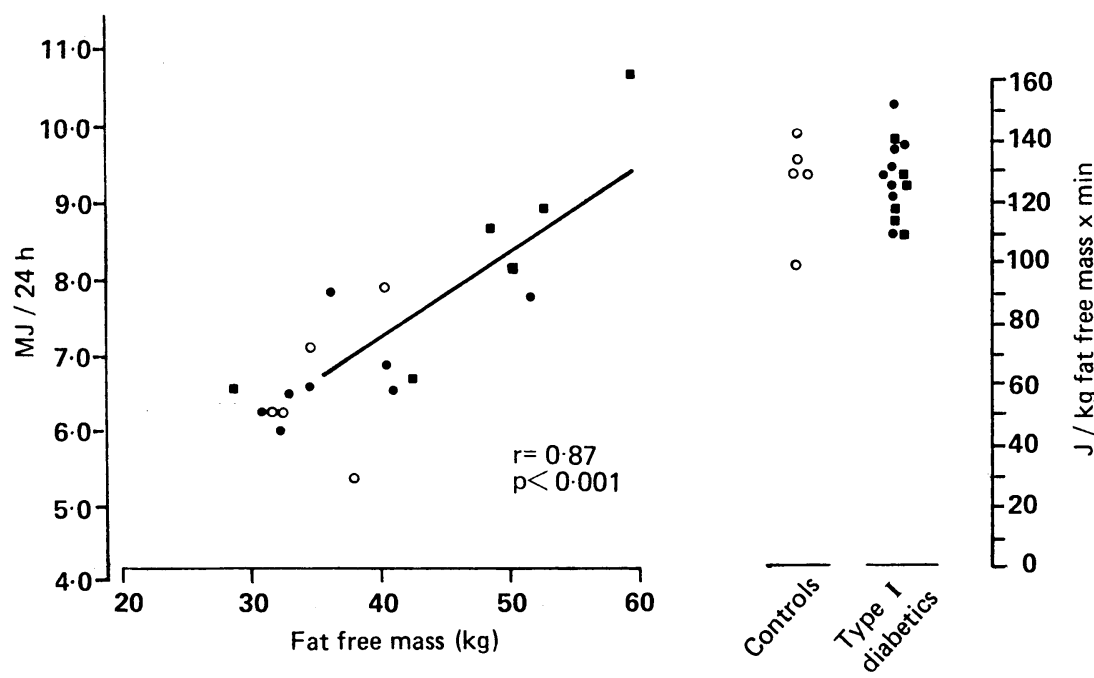

FIG 1-Resting metabolic rate as function of fat free mass in healthy children $(O)$ and children with type I diabetes differing with respect to glycaemic control ( glycated haemoglobin concentration $<10 \%(\bullet)$ or $\geqslant 10 \%(\bullet))$ acute metabolic decompensations or clinical signs of late complications. We investigated resting metabolic rate as well as the thermogenic response to an infusion of adrenaline.

\section{Methods \\ SUBJECTS}

Fourteen children with type I diabetes mellitus were selected from a total of 45 patients because they were free of clinically important signs of late complications of diabetes mellitus. None of them excreted C peptide in their urine and their degree of glycaemic control was routinely assessed. They were compared with five healthy control children who were recruited from among the children of members of our staff. All were familiar with laboratory and investigational procedures and volunteered for the study, their parents giving informed written consent. The study protocol was approved by the ethical committee of the medical school.

MD gave all subjects a complete medical examination to exclude late manifestations of diabetes mellitus. According to the results of Hilsted et al,${ }^{10}$ we especially looked for clinical signs of autonomic neuropathy from the medical history and physical examination. These signs were an increased resting pulse $(\geqslant 100$ beats $/ \mathrm{min}$ from electrocardiographic tracings after the subject had been lying supine for 15 minutes); beat to beat variations in heart rate during hyperventilation $(<10$ beats/min); abnormal $\mathrm{RR}$ ratios during the Valsalva manoeuvre (difference between the longest and shortest RR interval $\leqslant 1 \cdot 1$ ); a decline in systolic blood pressure on standing $(>30 \mathrm{~mm} \mathrm{Hg}$ ); a possible prolongation of cardiac repolarisation as reflected by the QT interval in response to changes in heart rate (corrected QT interval $>440 \mathrm{~ms}^{11}$ ); and clinical signs of diminished vibratory perception. At the same time we measured body weight, height, and body composition (tetrapolar bioelectrical impedance analysis with a radio frequency current of $800 \mu \mathrm{A}$ at $50 \mathrm{kHz}^{12}$; RJL Systems, Detroit). Experiments were performed on a separate day after this extensive clinical examination. None of the subjects had signs or symptoms of other diseases, endocrine or metabolic, or took drugs except insulin in the case of the diabetic children. All subjects ate a weight maintenance diet for at least a week before the study; none of the subjects reported significant changes in body weight during the three weeks before the study.

\section{EXPERIMENTAL PROTOCOL}

All investigations were performed after an overnight fast of 10 to 14 hours. The patients received conventional insulin treatment on the day before the study and injected their last dose of intermediate acting insulin at $9 \mathrm{pm}$. All subjects arrived in the metabolic ward at about $630 \mathrm{am}$. After voiding the subjects rested in a semirecumbent position in a quiet room with a constant temperature of $21-24^{\circ} \mathrm{C}$. A 19 gauge cannula (Butterfly, Abbott, Sligo, Republic of Ireland) was inserted into an antecubital vein, which was kept patent by infusing a minimum amount of $0.9 \%$ saline. The subjects were then asked to remain motionless and awake and were allowed 30 minutes to adjust to the environment. A steady pulse rate was taken to indicate a true resting metabolic rate, which was usually reached after 15 to 20 minutes.

Respiratory exchange measurements were taken 40 minutes before the experiment and until their end in a ventilated hood, open circuit, indirect calorimeter (Datex Instruments, Finland) as described previously. ${ }^{1314}$ The daily variation within subjects (based on test-retest measurements on three different days within two weeks in seven subjects) was below $10 \%$. The variability of indirect calorimetry based on propane combustion was $<4 \%$. Measurements were taken every minute, the results being averaged for

TABLE I-Clinical data on diabetic patients and control subjects

\begin{tabular}{|c|c|c|c|c|c|c|c|c|c|c|c|c|c|}
\hline & $\begin{array}{c}\text { Age } \\
\text { (years) }\end{array}$ & $\begin{array}{l}\text { Body } \\
\text { weight } \\
(\mathrm{kg})\end{array}$ & $\begin{array}{l}\text { Height } \\
(\mathrm{cm})\end{array}$ & $\begin{array}{c}\text { Body } \\
\text { mass index } \\
\left(\mathrm{kg} / \mathrm{m}^{2}\right)\end{array}$ & $\begin{array}{l}\text { Fat tissue } \\
\text { (\% body } \\
\text { weight })\end{array}$ & $\begin{array}{c}\text { Fat free } \\
\text { mass } \\
(\mathrm{kg})\end{array}$ & $\begin{array}{c}\text { Total } \\
\text { body water } \\
\text { (I) }\end{array}$ & $\begin{array}{l}\text { Duration } \\
\text { of diabetes } \\
\text { (months) }\end{array}$ & $\begin{array}{c}\text { Insulin } \\
\text { dose } \\
\text { (U/day) }\end{array}$ & $\begin{array}{c}\text { Glycated } \\
\text { haemoglobin } \\
(\%)\end{array}$ & $\begin{array}{l}\text { Plasma } \\
\text { glucose } \\
(\mathrm{mmol} / \mathrm{l})\end{array}$ & $\begin{array}{l}\text { Plasma } \\
\text { creatinine } \\
(\mu \mathrm{mol} / \mathrm{l})\end{array}$ & $\begin{array}{c}\text { Albuminuria } \\
(\mu \mathrm{mol} / \mathrm{min})\end{array}$ \\
\hline \multicolumn{14}{|c|}{ Type I diabetics } \\
\hline \multicolumn{14}{|l|}{ Case No (sex): } \\
\hline $1(M)$ & 13 & $42 \cdot 1$ & 156 & $17 \cdot 3$ & $20 \cdot 9$ & $33 \cdot 2$ & $30 \cdot 6$ & 102 & 52 & $7 \cdot 6$ & $8 \cdot 2$ & 27 & $1 \cdot 0$ \\
\hline $2(\mathrm{~F})$ & 14 & $45 \cdot 1$ & 146 & $21 \cdot 1$ & $34 \cdot 2$ & $29 \cdot 7$ & $25 \cdot 7$ & 88 & 54 & $13 \cdot 8$ & $18 \cdot 1$ & 18 & $38 \cdot 4$ \\
\hline $3(M)$ & 15 & $72 \cdot 0$ & 173 & $24 \cdot 0$ & $27 \cdot 0$ & $52 \cdot 6$ & $43 \cdot 1$ & 89 & 50 & $11 \cdot 0$ & $14 \cdot 4$ & 27 & $10 \cdot 6$ \\
\hline $4(\mathrm{M})$ & 13 & $44 \cdot 4$ & 166 & $16 \cdot 1$ & $22 \cdot 1$ & $34 \cdot 6$ & $31 \cdot 5$ & 51 & 42 & 6.9 & $3 \cdot 7$ & 35 & $5 \cdot 0$ \\
\hline $5(M)$ & 12 & $51 \cdot 0$ & 165 & $18 \cdot 7$ & $19 \cdot 6$ & $41 \cdot 0$ & $35 \cdot 6$ & 91 & 41 & $9 \cdot 0$ & $12 \cdot 0$ & 35 & $2 \cdot 0$ \\
\hline $6(M)$ & 17 & $70 \cdot 0$ & 184 & $20 \cdot 7$ & $25 \cdot 9$ & 51.8 & $41 \cdot 0$ & 92 & $42^{\star}$ & $9 \cdot 4$ & $11 \cdot 4$ & 44 & $2 \cdot 3$ \\
\hline $7(\mathrm{~F})$ & 16 & $58 \cdot 2$ & 166 & $21 \cdot 1$ & $30 \cdot 1$ & $40 \cdot 2$ & $32 \cdot 7$ & 42 & $50^{\star}$ & $7 \cdot 6$ & $8 \cdot 0$ & 35 & $3 \cdot 1$ \\
\hline $8(\mathrm{~F})$ & 17 & $71 \cdot 0$ & 173 & $23 \cdot 7$ & 31.9 & $48 \cdot 4$ & $38 \cdot 0$ & 149 & 80 & $10 \cdot 6$ & $13 \cdot 2$ & 27 & $30 \cdot 7$ \\
\hline $9(\mathrm{M})$ & 16 & $76 \cdot 6$ & 189 & $21 \cdot 4$ & $21 \cdot 7$ & $59 \cdot 6$ & $47 \cdot 7$ & 79 & 52 & $10 \cdot 1$ & $12 \cdot 9$ & 35 & $33 \cdot 1$ \\
\hline$\cdot 10(\mathrm{~F})$ & 16 & $64 \cdot 0$ & 175 & $20 \cdot 8$ & $33 \cdot 8$ & $42 \cdot 4$ & $32 \cdot 8$ & 118 & 54 & $12 \cdot 0$ & $7 \cdot 6$ & 53 & $2 \cdot 1$ \\
\hline $11(\mathrm{M})$ & 11 & $47 \cdot 0$ & 170 & $16 \cdot 3$ & $23 \cdot 5$ & $36 \cdot 1$ & $32 \cdot 2$ & 53 & 43 & $7 \cdot 2$ & 11.9 & 35 & $10 \cdot 8$ \\
\hline $12(\mathrm{~F})$ & 11 & $44 \cdot 0$ & 158 & $17 \cdot 6$ & $28 \cdot 5$ & $31 \cdot 5$ & $26 \cdot 8$ & 45 & 38 & $7 \cdot 5$ & $14 \cdot 5$ & 35 & 1.6 \\
\hline $13(F)$ & 11 & $40 \cdot 1$ & 154 & $16 \cdot 9$ & $19 \cdot 1$ & $32 \cdot 4$ & $29 \cdot 5$ & 101 & 25 & $7 \cdot 9$ & 11.5 & 27 & $8 \cdot 4$ \\
\hline $14(M)$ & 17 & $64 \cdot 0$ & 172 & $21 \cdot 6$ & 21.6 & $50 \cdot 2$ & $41 \cdot 6$ & 125 & 64 & $14 \cdot 3$ & $9 \cdot 7$ & 44 & 3.0 \\
\hline \multicolumn{14}{|l|}{ Mean values ( $\mathrm{SD}$ ): } \\
\hline All $(n=14)$ & $14(2)$ & $56 \cdot 4(12 \cdot 9)$ & $167(12)$ & $19 \cdot 8(2 \cdot 6)$ & $25 \cdot 7(5 \cdot 3)$ & $41 \cdot 7(9 \cdot 4)$ & $34.9(6 \cdot 5)$ & $88(32)$ & $49(13)$ & $9 \cdot 6(2 \cdot 4)$ & $11 \cdot 2(3 \cdot 6)$ & $34(9)$ & $10 \cdot 9(12 \cdot 1)$ \\
\hline $\begin{array}{l}\text { Glycated haemoglobin }(\%): \\
<10(n=8)\end{array}$ & & $49 \cdot 6(10 \cdot 0)$ & $165(10)$ & $18 \cdot 1(1 \cdot 9)$ & $23 \cdot 7(4 \cdot 1)$ & $37 \cdot 6(6 \cdot 7)$ & $32 \cdot 5(4 \cdot 2)$ & $61(31)$ & $42(8)$ & $7.9(0.9)$ & $10 \cdot 2(3 \cdot 4)$ & $34(5)$ & $4 \cdot 3(3 \cdot 6)$ \\
\hline$\geqslant 10(n=6)$ & $16(1)$ & $65 \cdot 5(11 \cdot 1)$ & $171(14)$ & $22 \cdot 1(1 \cdot 4)$ & $28 \cdot 4(5 \cdot 8)$ & $47 \cdot 1(10 \cdot 2)$ & $38 \cdot 2(7 \cdot 9)$ & $108(27)$ & $59(11)$ & $12 \cdot 0(1 \cdot 7)$ & $12 \cdot 7(3 \cdot 7)$ & $34(13)$ & $19 \cdot 7(16 \cdot 3)$ \\
\hline \multicolumn{14}{|c|}{ Control subjects } \\
\hline $\begin{array}{l}\text { Mean values (SD): } \\
\quad \text { All }(\mathbf{n}=5)\end{array}$ & $13(1)$ & $47 \cdot 8(8 \cdot 9)$ & $161(7)$ & $18 \cdot 8(1 \cdot 3)$ & $27 \cdot 4(7 \cdot 6)$ & $35 \cdot 2(3 \cdot 6)$ & $30 \cdot 6(1 \cdot 7)$ & & & $2 \cdot 1(2 \cdot 6)$ & $3 \cdot 3(0 \cdot 4)$ & & $4 \cdot 8(3 \cdot 9)$ \\
\hline
\end{tabular}

^Intensified conventional treatment. 
TABLE II - Heart rate, mean arterial blood pressure, work done by heart, oxygen consumption, respiratory quotient, and urinary nitrogen excretion in three study groups during basal period

Type I diabetics $(n=14)$

\begin{tabular}{lccc} 
& $\begin{array}{c}\text { Controls } \\
(\mathrm{n}=5)\end{array}$ & $\begin{array}{c}\text { Glycated haemoglobin } \\
<10 \%(\mathrm{n}=8)\end{array}$ & $\begin{array}{c}\text { Glycated haemoglobin } \\
\geqslant 10 \%(\mathrm{n}=6)\end{array}$ \\
\hline Heart rate (beats/min) & $79(8)$ & $79(14)$ & $75(5)$ \\
Mean arterial blood pressure $(\mathrm{mm} \mathrm{Hg})$ & $80(7)$ & $72(8)$ & $80(6)$ \\
Heart work & $6.34(1.09)$ & $5.63(1.06)$ & $6.07(0.77)$ \\
Oxygen consumption $(\mathrm{ml} / \mathrm{min})$ & $225(35)$ & $225(90)$ & $275(61)$ \\
Respiratory quotient & $0.86(0 \cdot 06)$ & $0.82(0.03)$ & $0.79(0.04) \dagger$ \\
Urinary nitrogen excretion $(\mathrm{mg} / \mathrm{min})$ & $5.4(3.0)$ & $11.5(5.4) \dagger$ & $11.6(5 \cdot 2) \dagger$ \\
\hline
\end{tabular}

${ }^{\star}$ Heart rate $\times$ mean arterial blood pressure $\times 1000$.

tp $<0.05$ compared with controls.

TABLE III-Plasma concentrations of glucose, lactate, free fatty acids, and $\beta$-hydroxybutyrate before and after adrenaline infusion in three study groups. Figures are means (SD)

\begin{tabular}{|c|c|c|c|c|}
\hline & \multirow[b]{2}{*}{$\begin{array}{c}\text { Adrenaline } \\
\text { infusion } \\
(\text { min })\end{array}$} & \multirow[b]{2}{*}{$\begin{array}{c}\text { Controls } \\
(\mathrm{n}=5)\end{array}$} & \multicolumn{2}{|c|}{ Type I diabetics $(n=14)$} \\
\hline & & & $\begin{array}{l}\text { Glycated haemoglobin } \\
<10 \%(n=8)\end{array}$ & $\begin{array}{l}\text { Glycated haemoglobin } \\
\geqslant 10 \%(n=6)\end{array}$ \\
\hline Glucose (mmol/l) & $\left\{\begin{array}{r}0 \\
45\end{array}\right.$ & $\begin{array}{l}3.26(0.39) \\
3.90(0 \cdot 64)\end{array}$ & $\begin{array}{l}10 \cdot 2(3 \cdot 4)^{\star} \\
12 \cdot 2(3 \cdot 1)^{\star}\end{array}$ & $\begin{array}{l}12 \cdot 7(3 \cdot 7)^{\star} \\
15 \cdot 5(2 \cdot 9)^{\star} \dagger\end{array}$ \\
\hline Lactate $(\mathrm{mmol} / \mathrm{l})$ & $\left\{\begin{array}{r}0 \\
45\end{array}\right.$ & $\begin{array}{l}1.04(0.39) \\
1.53(1.05)\end{array}$ & $\begin{array}{l}0.91(0.23) \\
1.07(0.28)\end{array}$ & $\begin{array}{l}1.02(0 \cdot 23) \\
1 \cdot 25(0 \cdot 24)\end{array}$ \\
\hline Free fatty acids $(\mathrm{mmol} / \mathrm{l})$ & $\left\{\begin{array}{r}0 \\
45\end{array}\right.$ & $\begin{array}{l}1.27(0.29) \\
1.76(0.28) \dagger\end{array}$ & $\begin{array}{l}1.57(0.60) \\
3.40(0.60)^{\star} \dagger\end{array}$ & $\begin{array}{l}1.99(0.54)^{\star} \\
3.21(0.54)^{\star} \dagger\end{array}$ \\
\hline (3-Hydroxybutyrate $(\mathrm{mmol} / \mathrm{l})$ & $\left\{\begin{array}{r}0 \\
45\end{array}\right.$ & $\begin{array}{l}0.13(0.09) \\
0.69(0.45) \dagger\end{array}$ & $\begin{array}{l}0.84(0.45)^{\star} \\
1.58(0.59)^{\star} \dagger\end{array}$ & $\begin{array}{l}1.32(1.19)^{\star} \\
2.55(1.35)^{\star} \dagger\end{array}$ \\
\hline
\end{tabular}

${ }^{\star} \mathrm{p}<0.05$ compared with controls.

tp $<0.01$ compared with values before adrenaline infusion.
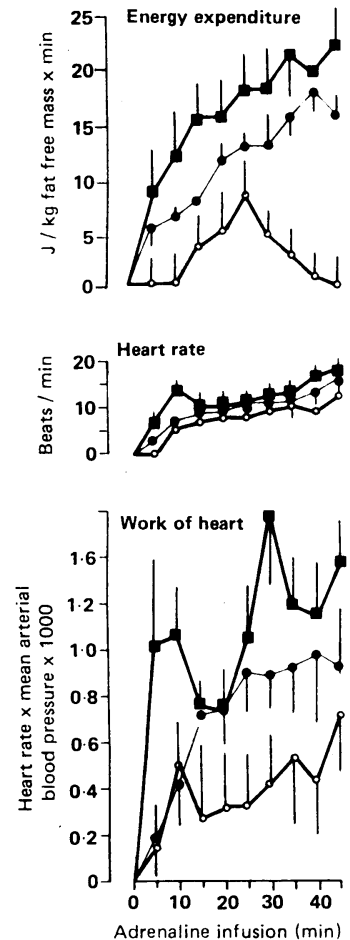

FIG 2-Increases in energy expenditure, heart rate, and work of heart during adrenaline infusion in healthy children $(0)$ and children with type I diabetes differing with respect to glycaemic control (glycated haemoglobin concentration $<10 \%(\bullet)$ or $\geqslant 10 \%(\bullet))$. Data are means $(S D)$ Urine was collected overnight and during the test and periods of five minutes. Calibrations were performed immediately before and at the end of the measurements. Heart rate was measured directly from electrocardiograms (Hellige Instruments, Kiel, Federal Republic of Germany), and blood pressure was recorded by the indirect auscultatory method every five minutes. A baseline period of 30 minutes was used to calculate resting metabolic rate. During this time the coefficients of variation for oxygen consumption and carbon dioxide production were $<5 \%$. At about 8 am (time zero) adrenaline (Suprarenin) $1 \mathrm{~g} / \mathrm{l}$ diluted in $0.9 \%$ saline containing ascorbic acid $1 \mathrm{~g} / \mathrm{l}$ (Hoechst, Frankfurt, Federal Republic of Germany) was infused at a rate of $0.03 \mu \mathrm{g} / \mathrm{kg}$ fat free mass $\times$ min for 45 minutes. Blood samples were drawn five minutes before the start of the infusion and immediately afterwards and analysed for metabolites (urea nitrogen, glucose, lactate, free fatty acids, and $\beta$-hydroxybutyrate) and catecholamines as described previously. . $^{13-15}$ analysed for urea nitrogen and for albumin with rabbit antibodies to human albumin.

\section{DATA ANALYSES}

Substrate oxidation rates were calculated according to previously reported methods. ${ }^{1314}$ The following constants were used: (a) $6 \cdot 25 \mathrm{~g}$ of protein produces $1 \mathrm{~g}$ urinary nitrogen; $(b) 966.3 \mathrm{ml}$ oxygen is used to oxidise $1 \mathrm{~g}$ protein, which produces $773.9 \mathrm{ml}$ carbon dioxide; $(c)$ the respiratory quotient is 0.707 for complete lipid oxidation and 1.000 for complete glucose oxidation; and $(e)$ the oxygen consumed per gram of substrate oxidised is 2.0191 for fat, 0.8291 for glycogen, and 0.7461 for glucose. Protein oxidation was calculated from the urinary excretion of nitrogen after correction for changes in the urea pool. ${ }^{1314}$ Body composition was calculated as previously described. ${ }^{16}$ Mean arterial pressure was calculated as a third of (systolic pressure-diastolic pressure)+diastolic pressure. The product of mean arterial blood pressure and heart rate was considered to be an index of the work done by the heart."

Data were analysed by using analysis of variance corrected for repeated measurements to compare the overall effects within the groups. Student's unpaired $t$ test (two tailed) was used to compare the means between the groups (control $v$ diabetic); a $\mathrm{p}$ value of $<0.05$ was considered to be significant. The cumulative incremental response was calculated from the area under the response curve above basal values. Spearman's correlation coefficients were used to assess the association between free fatty mass and energy expenditure. All data are given as means (SD).

\section{Results}

\section{CLINICAL DATA}

Table I gives the physical and clinical characteristics of the subjects. The patients with poorly controlled diabetes (glycated haemoglobin concentration $\geqslant 10 \%$ ) had had the disease significantly longer than those with a glycated haemoglobin concentration of $<10 \%$. A significant difference was also observed for the daily doses of insulin injected but not for basal plasma glucose concentrations. None of the children had clinically important signs of neuropathy (data not shown). None of the patients had background retinopathy; three had moderate microalbuminuria, which was defined as an albumin excretion of $>20 \mu \mathrm{g} / \mathrm{min}$ (table I).

\section{DATA DURING BASAL PERIOD}

When compared with the control children the diabetic children showed no significant changes in heart rate, the work done by the heart, and basal oxygen consumption, but they had a lower respiratory quotient and an increased urinary nitrogen excretion, which both indicate tissue catabolism (table II).

No differences were observed in resting metabolic rate expressed as $\mathrm{kJ} / \mathrm{min}, \mathrm{J} / \mathrm{kg}$ body weight $\times \min$, or $\mathrm{J} / \mathrm{kg}$ fat free mass $\times \min$ (fig 1). There was a close correlation between fat free mass and resting metabolic rate which was independent of diabetes mellitus and the degree of glycaemic control (in control subjects the value was $126.4(15.5) \mathrm{J} / \mathrm{kg}$ fat free mass $\times \min$, in diabetic children with glycated haemoglobin concentration $<10 \% \quad 121.3 \quad(19.2) \quad \mathrm{J} / \mathrm{kg}$ fat free mass $\times \min$, and in diabetics with a glycated haemoglobin concentration $\geqslant 10 \% 123.4(10.0) \mathrm{J} / \mathrm{kg}$ fat free mass $\times \min )$. Basal energy expenditure in the five diabetic children with a basal plasma glucose concentration $<10 \mathrm{mmol} / \mathrm{l}(7 \cdot 44(2 \cdot 24) \mathrm{mmol} / \mathrm{l})$ was $123 \cdot 4(10 \cdot 6) \mathrm{J} / \mathrm{kg}$ fat free mass $\times$ min, which was similar to the value obtained in the nine patients with a basal glucose concentration $\geqslant 10 \mathrm{mmol} / \mathrm{l}(125 \cdot 9(13 \cdot 1) \mathrm{J} / \mathrm{kg}$ fat free mass $\times$ min; plasma glucose concentration $13 \cdot 3$ $(2 \cdot 13) \mathrm{mmol} / \mathrm{l})$. In the three patients with significant microalbuminuria recalculation gave a mean of $129 \cdot 3$ $(6.8) \mathrm{J} / \mathrm{kg}$ fat free mass $\times$ min. The average deviation between estimated and measured resting metabolic rate was about $13 \%$ and did not differ between the healthy and diabetic children. This finding indicates that we did not measure the "true" resting metabolic rate in our patients despite the fact that their pulse rate had reached a stable steady state.

From the values of urinary nitrogen excretion and respiratory quotient (table II) glucose oxidation rate was significantly decreased in the diabetic children with a concomitant significant increase in lipid oxidation $(p<0.05$; see figure 4$)$. Protein oxidation was significantly increased in the diabetic children $(72$ (32) $\mathrm{mg} / \mathrm{min}$ in all diabetics, $86(45) \mathrm{mg} / \mathrm{min}$ in those with a glycated haemoglobin value $<10 \%$, and $70(29)$ in those with a glycated haemoglobin value $\geqslant 10 \% v 34$ (19) in control subjects). Thus diabetes shifted the endogenous fuel $\mathrm{mix}$ from $49 \%$ carbohydrates, $39 \%$ lipids, and $12 \%$ protein in control subjects to corresponding values of $25 \%, 49 \%$, and $27 \%$ respectively in the diabetic children as a group. In the 


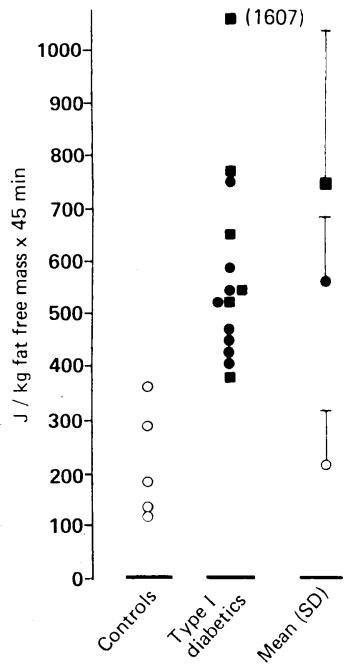

FIG 3-Increases in

thermogenesis induced by adrenaline in healthy children (O) and children with type I diabetes differing with respect to glycaemic control (glycated haemoglobin concentration $<10 \%(\bullet)$ or $\geqslant 10 \%(\square))$. Data are areas under response curves
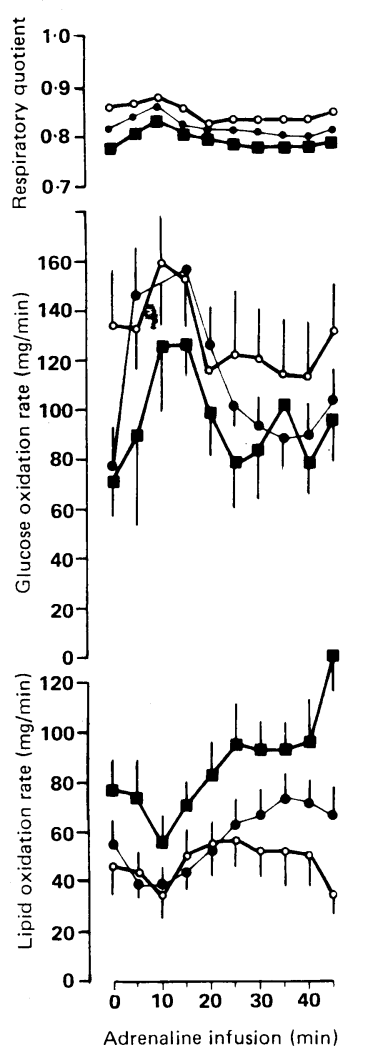

FIG 4-Increases in respiratory quotient and rates of glucose and lipid oxidation in healthy children $(O)$ and children with type I diabetes differing with respect to glycaemic control (glycated haemoglobin concentration $<10 \%(\bullet)$ or $\geqslant 10 \%(\mathrm{M})$ ). Data are mean $(S D)$ diabetics with a glycated haemoglobin concentration $<10 \%$ the values were $27 \%$ carbohydrate, $43 \%$ protein, and $30 \%$ lipids; in those with a glycated haemoglobin concentration $\geqslant 10 \%$ the values were $22 \%, 56 \%$, and $22 \%$. Plasma concentrations of free fatty acids and ketones were increased concomitantly in patients with poorly controlled type I diabetes (table III). Basal plasma catecholamine concentrations did not differ between control and diabetic children (controls $v$ diabetics: adrenaline 879 (382) pmol/l $v$ $1048(355) \mathrm{pmol} / \mathrm{l}$, noradrenaline $2.61(0.89) \mathrm{nmol} / \mathrm{l} v$ $2.34(0.53) \mathrm{nmol} / \mathrm{l}$, dopamine $470(89) \mathrm{pmol} / \mathrm{l} v 484$ (41) $\mathrm{pmol} / \mathrm{l})$.

\section{DATA DURING ADRENALINE INFUSION}

The infusion of adrenaline increased plasma catecholamine concentrations in both groups (adrenaline in control group 2380 (846) $\mathrm{pmol} / 1$ v 2713 (961) $\mathrm{pmol} / \mathrm{l}$ in the diabetic group; noradrenaline $2 \cdot 7$ $(1.19) \mathrm{nmol} / \mathrm{l} v 2.96(0.79) \mathrm{nmol} / \mathrm{l}$, and dopamine 504 (68) pmol/l $v 804$ (109) pmol/l); it also increased heart rate, the work done by the heart, and energy expenditure (fig 2). The effect on energy expenditure was most pronounced and sustained in the diabetic children, whereas a transient response was seen in the healthy control children (fig 2). The maximal increases in oxygen consumption were $18(12) \mathrm{ml} / \mathrm{min}$ in control subjects compared with $40(13) \mathrm{ml} / \mathrm{min}$ in the diabetic children $(p<0.01)$. The maximal increase in the diabetic children with glycated haemoglobin concentrations $<10 \%$ was $35(10) \mathrm{ml} / \mathrm{min}$ as compared with 44 (17) $\mathrm{ml} / \mathrm{min}$ in those with a concentration $\geqslant 10 \%$ (NS).

The areas under the response curves showed that the thermogenesis induced by adrenaline was increased by a factor of three in the diabetic children (fig 3). No significant differences were observed between groups of patients differing with respect to their glycaemic control (figs 3 and 4) or in a subgroup of nine patients with basal plasma glucose concentrations $\geqslant 10 \mathrm{mmol} / 1$ (699 (364) $\mathrm{J} / \mathrm{kg}$ fat free mass $\times 45 \mathrm{~min}$, mean glucose concentration $13 \cdot 3(2 \cdot 13) \mathrm{mmol} / \mathrm{l})$. The five patients with a basal glucose concentration $<10 \mathrm{mmol} / 1$ also showed increased thermogenesis $(519$ (100) J/kg fat free mass $\times 45$ min, mean glucose concentration $7 \cdot 44$ $(2 \cdot 24) \mathrm{mmol} / \mathrm{l})$. No correlation was found between the thermogenic effect of adrenaline and the indices of glycaemic control - that is, basal plasma glucose and glycated haemoglobin concentrations (data not shown).

Urinary nitrogen excretion was significantly raised during the infusion of adrenaline in the diabetic children $(11.0(4 \cdot 1) \mathrm{mg} / \mathrm{min})$ compared with the control subjects $(6.5(2.4) \mathrm{mg} / \mathrm{min} ; \mathrm{p}<0.05)$. The mean value in diabetic children with a glycated haemoglobin concentration $<10 \%$ was $11 \cdot 7(4 \cdot 5) \mathrm{mg} / \mathrm{min}$ and in those with a glycated haemoglobin concentration $\geqslant 10 \% 9 \cdot 2(3 \cdot 1) \mathrm{mg} / \mathrm{min}$. With regard to the endogenous fuel mix adrenaline increased the rate of glucose oxidation in all groups and at raised rates of lipid oxidation in diabetic children (fig 4). Table III shows that adrenaline significantly increased the plasma glucose concentration in the diabetic children and increased plasma concentration of free fatty acids and ketone bodies in all of the subjects. No significant increases were observed in plasma lactate concentrations. The average increases in glucose concentration were $0.65(0.39) \mathrm{mmol} / \mathrm{l}$ (control subjects), 2.03 $(1 \cdot 13) \mathrm{mmol} / \mathrm{l}$ (diabetic children with a glycated haemoglobin concentration $<10 \% ; \mathrm{p}<0.05$ compared with control group), and $2.82(1.51) \mathrm{mmol} / \mathrm{l}$ (diabetic children with a glycated haemoglobin concentration $\geqslant 10 \% ; \mathrm{p}<0.05$ compared with control group). The corresponding values for free fatty acid concentrations were $0.49(0.29) \mathrm{mmol} / 1$ (control subjects), 1.82 $(0.90) \mathrm{mmol} / \mathrm{l}$ (diabetic children with a glycated haemoglobin concentration $<10 \%$; $<<0.05$ compared with control subjects), and $1 \cdot 22(0 \cdot 49) \mathrm{mmol} / \mathrm{l}$ (diabetic children with a glycated haemoglobin concentration $\geqslant 10 \% ; \mathrm{p}<0.05$ compared with control subjects). The average increases in $\beta$-hydroxybutyrate concentration were $0.56(0.48) \mathrm{mmol} / \mathrm{l}$ (control subjects), 0.70 $(0 \cdot 11) \mathrm{mmol} / \mathrm{l}$ (diabetic children with a glycated haemoglobin concentration $<10 \%$ ), and $1 \cdot 23$ $(0 \cdot 79) \mathrm{mmol} / \mathrm{l}$ (diabetic children with a glycated haemoglobin concentration $\geqslant 10 \%$ ).

\section{Discussion}

Alterations in the components of energy expenditure may contribute to a positive energy balance in obese subjects and patients with type II diabetes. ${ }^{12}$ In such patients a low resting metabolic rate and a blunted thermogenic response to different stimuli may result in tissue anabolism and weight gain. In contrast with patients with type II diabetes those with type I diabetes are commonly prone to tissue catabolism and weigh loss. This is shown by their increased urinary excretion of nitrogen and methylhistidine ${ }^{18}$ as well as their raised plasma concentrations of free fatty acids and consequently lipid oxidation and plasma concentrations of ketone bodies (fig 4 and table III).

Although they are not proved by a prospective longitudinal study and are on only a few subjects, our data give evidence for a normal resting metabolic rate (fig 1, table II) and for a threefold and sustained increase in the thermogenic effect of adrenaline in children with type I diabetes (figs 2 and 3). Amplifying the thermogenic effect of adrenaline may result in long term energy deficit of about $630 \mathrm{~kJ}$ a day, which is about $10 \%$ of the resting metabolic rate observed in children with type I diabetes (fig 1). Our experimental model resembles what happens during moderate stress as we detected maximum plasma adrenaline concentrations of about $2700 \mathrm{pmol} / \mathrm{l}$. The increased thermogenic effect of adrenaline may partly explain the pronounced tissue wasting observed during intercurrent stress-for example, an infection-in children with type I diabetes. An increased sensitivity to adrenaline agrees with previous data observed in adults with type I diabetes. ${ }^{9} 10$

Type I diabetes not only exaggerates the thermogenic effect of adrenaline but also affects the endogenous fuel mix. Glucose was still preferably oxidised during the acute response to stress - that is, the first 15 minutes but lipid and protein oxidation predominated during further metabolic adaptation to the stimulus (fig 4). These findings resemble a state of "accelerated starvation" and explain the accelerated loss of adipose tissue as well as lean body mass in diabetic children during moderate and severe stress. The respiratory quotient may, however, be affected over a few minutes by minor changes in the rate of breathing and any changes will have partly contributed to our data but will not have affected the differences between the groups.

The increased thermogenic effect of adrenaline observed in children with type I diabetes mellitus is most probably independent of their glycaemic control. This idea is supported by previous data ${ }^{8-10}$ In addition, we found no correlation between the sensitivity to adrenaline and glycaemic control. Even the patient with the best glycaemic control (glycated haemoglobin concentration $6 \cdot 7 \%$, basal plasma glucose $3.7 \mathrm{mmol} / \mathrm{l}$ ) showed a $2 \cdot 4$-fold increase in thermogenesis when compared with the healthy control children. To be absolutely sure about this idea, however, the infusion of adrenaline should have been repeated after plasma glucose concentration had been normalised in the short term-for example, after using an overnight euglycaemic clamp. This was considered to be 
unreasonable for our children. Similar methods were used in adults with type I diabetes and showed that an enhanced metabolic response to adrenaline-that is, a significant increase in plasma concentrations of glycerol, free fatty acids, lactate, and glucose and in the rate of glucose production - also occurs after glycaemia has been normalised using a clamp. ${ }^{10}$ These data also suggest that hyperglycaemia does not affect the sensitivity to adrenaline and support our idea that our results cannot be explained as being simply the result of a lack of insulin. ${ }^{910}$ Glycaemic control therefore might not mean metabolic control, which is against the current clinical view. This might be explained by the idea that the whole picture of metabolic events observed in type I as well as type II diabetes results from different metabolic lesions within the metabolism of glucose, lipids, and amino acids. With regard to the dose-response curves of insulin lipid oxidation, hepatic glucose production, carbohydrate oxidation, glucose storage, and amino acid oxidation all show different insulin sensitivities - that is, half maximal effects are observed at plasma insulin concentrations ranging between 29 and $213 \mathrm{mU} / 1 .{ }^{19-21}$ These data suggest that a given plasma insulin concentration may be sufficient to normalise blood glucose concentrations but protein turnover, for instance, may still be disturbed. To achieve optimal metabolic (instead of glycaemic) control in diabetic patients the need to study variables other than plasma glucose concentration is obvious.

We conclude that our observations may have important clinical implications for patients with type I diabetes mellitus. Such patients are commonly prone to tissue catabolism which is obvious during intercurrent stress-for example, an infection. As an increased metabolic response to adrenaline has also been reported for fasting, ${ }^{22}$ malnutrition, ${ }^{23}$ hyperthyroidism, ${ }^{24}$ and sepsis ${ }^{25}$ an energy deficit due to increased thermogenesis may provide a rationale for tissue wasting during catabolism.

We thank Mrs S Ohlendorf for technical help, Dr A Balks for determining urinary albumin concentrations, and Mrs M Bürger for helping to prepare the manuscript. This work was presented in part at the 23rd annual meeting of the Deutsche Diabetes-Gesellschaft in Tübingen in May 1988 and contains part of MD's doctoral thesis. This work was supported by a grant from Braun Melsungen, Melsungen, Federal Republic of Germany.

1 Garrow JS. Energy balance in man-an overview. Am $\mathcal{f}$ Clin Nutr 1987;45: $114-9$

\section{Changing belief in iridology after an empirical study}

\section{Paul Knipschild}

Department of

Epidemiology and Health

Care Research,

University of Limburg, PO

Box 616, 6200 MD

Maastricht, The

Netherlands

Paul Knipschild, MD,

professor of epidemiology

BrMed J 1989;299:491-2
2 Sims EAH, Danforth E Jr. Expenditure and storage of energy in man. $f$ Clin Invest 1987;79:1019-25.

3 DeFronzo RA, Simonson D, Ferranninni E. Hepatic and peripheral insulin resistance: a common feature of type 2 (non-insulin-dependent) and type 1
(insulin-dependent) diabetes mellitus. Diabetologia 1982;23:313-9.

4 Proietto J, Nankervis A, Aitken P, Caruso G, Alford F. Glucose utilization in type 1 (insulin-dependent) diabetes: evidence for a defect not reversible by acute elevations of insulin. Diabetologia 1983;25:331-5.

5 Yki-Järvinen H, Koivisto VA. Natural course of insulin resistance in type 1 diabetes. $N$ Engl f Med 1986;315:224-30

6 Nair KS, Halliday D, Garrow JS. Increased energy expenditure in poorly controlled type 1 (insulin-dependent) diabetic patients. Diabetologia 1984;27:13-6.

7 Home PD, Capaldo B, Burin JM, Worth R, Alberti KGMM. A crossover comparison of continuous subcutaneous insulin infusion (CSII) agains multiple injections in insulin-dependent diabetic subjects. Improved contro with CSII. Diabetes Care 1982;5:457-65.

8 Leslie P, Jung RT, Isles TE, Baty J, Newton RW, Illingworth P. Effect of optimal glycaemic control with continuous subcutaneous insulin infusion on energy expenditure in type I diabetes mellitus. Br Med F 1986;293:1121-6.

9 Shamoon H, Hendler R, Sherwin RS. Altered responsiveness to cortisol, epinephrine, and glucagon in insulin-infused juvenile onset diabetics. epinephrine, and glucagen
Diabetes 1980;29:284-91.

10 Hilsted J, Richter E, Madsbad S, et al. Metabolic and cardiovascular responses to epinephrine in diabetic autonomic neuropathy. $N$ Engl f Med 1987;317 $421-6$

11 Kahn J, Sisson JC, Vinik AI. QT interval prolongation and sudden cardiac death in diabetic autonomic neuropathy. $\mathcal{F}$ Clin Endocrinol Metab 1987;64 751-4.

12 Lukaski HC, Johnson PE, Bolonchuk WW, Lykken GI. Assessment of fat fre mass using bioelectrical impedance measurements of the human body. Am f Clin Nutr 1985;41:810-7.

13 Müller MJ, Acheson KJ, Jequier E, Burger AG. Effect of thyroid hormones on oxidative and nonoxidative glucose metabolism in humans. Am $\mathcal{f}$ Physiol 1988;255: E146-52.

14 Müller MJ, Burger AG, Ferranninni E, Jequier E, Acheson KJ. Glucoregulatory function of thyroid hormones: role of pancreatic hormones. Am f Physiol 1989;259: E101-10.

15 Müller MJ, Paschen U, Seitz HJ. Effect of ketone bodies on glucose production and utilization in the miniature pig. $\mathcal{F}$ Clin Invest 1984;74: production.

16 Abu Khaled M, McCutcheon MJ, Reddy S, Pearman PL, Hunter GR, Weinsier RL. Electrical impedance in assessing human body composition: the BIA method. Am f Clin Nutr 1988;47:789-92.

17 Kitamara K, Jorgensen CR, Gobel L, Taylor H, Wang Y. Hemodynami correlates of myocardial oxygen consumption during upright exercise. J Appl Physiol 1972;32:516-22.

18 Huszar G, Koivisto V, Davis E, Felig P. Urinary methylhistidine excretion in juvenile-onset diabetics: evidence of increased protein catabolism in the absence of ketoacidosis. Metabolism 1982;31:188-91.

19 Rizza RA, Mandarino LJ, Gerich JE. Dose-response characteristics for effects of insulin on production and utilization of glucose. Am F Physiol 1981;240: E630-9.

20 Fukagawa NK, Minaker KL, Rose JW, et al. Insulin-mediated reduction of whole body protein breakdown: dose-response effects on leucine of whole body protein breakdown: dose-response effects on

21 Young AA, Bogardus $C$, Stone $K$, Mott DM. Insulin response of components of whole-body and muscle carbohydrate metabolism in humans. Am f Physiol 1988;254:E231-6.

22 Jensen MD, Haymond MW, Gerich JE, Cryer PE, Miles JM. Lipolysis during fasting. Decreased suppression by insulin and increased stimulation by epinephrine. I Clin Invest 1987;79:207-13.

23 Jayarajan MP, Shetty PS. Cardiovascular $\beta$-adrenoreceptor sensitivity in undernourished subjects. Br F Nutr 1987;58:5-11

24 Gelfand RA, Hutenson-Williams KA, Bode AA, Castellino R, Sherwin RS Catabolic effects of thyroid hormone excess. The contribution of adrenergic activity to hypermetabolism and protein breakdown. Metabolism 1987;36:562-9.

25 Forse RA, Leibel R, Ashkanazy J, Hirsch J, Kinney MJ. Adrenergic control of adipocyte lipolysis in trauma and sepsis. Ann Surg 1987;206:744-51.

(Accepted 16 May 1989)

\section{Subjects, methods, and results}

I performed the inquiry among the first authors of recent papers in the BMF, the fournal of the Royal College of General Practitioners, and three journals of alternative medicine (British Fournal of Homoeopathy, Allgemeine Homöopathische Zeitung, and Acupuncture and Electro-therapeutics Research). In all, 100, 40, and 60 authors respectively were invited to state their belief in iridology by indicating, as a percentage, their belief in the hypothesis that "for certain diseases iridology is a useful diagnostic aid" on a visual analogue scale three weeks before the paper on iridology was published. ${ }^{1}$ To prevent bias I selected only authors who did not know me, and all of the information was gathered by post.

Of the 200 authors contacted, 83 responded. The paper was sent to them with the request to read it carefully and afterwards reassess their belief. Five of them did not reply in spite of two reminders. The response rate was therefore $39 \%(40 \%, 50 \%$, and $30 \%$ for authors of papers in the BMF, $\mathcal{F} R$ Coll Gen Pract, and the journals of alternative medicine respectively).

The figure summarises the data on the 78 respondents. Fifteen authors (10 of papers in the $B M F$, four of papers in $\mathcal{F} R$ Coll Gen Pract, and one of a paper in a journal of alternative medicine) who did not believe in iridology before they read the report (belief $<10 \%$ ) did not change their opinion after reading it. Three 